\title{
Professores universitários que escrevem livros didáticos: análise de depoimentos de autores brasileiros contemporâneos
}

Décio Gatti Júnior

RESUMO

Trata-se da comunicação das reflexões histórico-pedagógicas realizadas no âmbito da História das Disciplinas Escolares, na qual a perspectiva de análise foi a sócio-histórica, voltada para o exame dos conteúdos dos depoimentos recolhidos, no final dos anos 90 do Século XX, junto a alguns professores universitários da região sudeste e nordeste do Brasil que também se tornaram, a partir do final dos anos sessenta e inicio dos anos setenta, importantes autores de livros didáticos de História no Brasil. Nesta reflexão foram levantados e analisados os dados biográficos dos autores, em especial: a formação acadêmica, a experiência docente em sala de aula, o itinerário e os impactos do regime militar e da redemocratização sobre sua produção didática, o entendimento sobre a função do livro didático e sobre a forma como os conteúdos veiculados contribuem para a formação da memória nacional. 0 empreendimento editorial ligado à produção didática exige, atualmente, autores que agreguem capacidade de redação em linguagem acessível, com condições de atualização freqüente dos conteúdos e que se disponham a compartilhar com diversos outros profissionais a responsabilidade pela produção de sua obra didática.

Palavras-chave: professor universitário, livro didático, memória nacional.

Grande parte dos autores dos livros didáticos de História produzidos nas últimas três décadas tem um perfil bastante diferenciado daqueles que escreviam os manuais escolares até meados dos anos sessenta. Se antes os autores trabalhavam praticamente sozinhos, tendo a companhia quase que exclusiva do editor, que geralmente também era o dono da empresa, hoje em dia, os

1. Professor de História da Educação do Centro Universitário do Triângulo e da Universidade Federal de Uberlândia/MG. 
autores têm contato com editores especializados, que fazem parte de uma enorme estrutura organizacional e, portanto, permanecem afastados dos centros de poder dessas empresas.

Este trabalho está ancorado nos depoimentos recolhidos no final dos anos noventa junto a quatro importantes autores de livros didáticos brasileiros que exercem a função docente e, em alguns casos, a função de investigador, em instituições de educação superior no Brasil.

A primeira, Prof ${ }^{a}$. Joana Neves, que reside na Paraíba e trabalha com livros didáticos desde 1975, sendo que o livro "História do Brasil", destinado aos alunos do o Ensino Médio, é obra conhecida dos docentes em História de todo país. Este, a semelhança dos demais livros didáticos publicados pela autora, sempre tiveram como co-autora a professora Elza Nadai, já falecida. No final dos anos noventa, Joana Neves, era professora aposentada pela UFPB, trabalha com pesquisa e assessora a UFPE.

0 segundo, Prof. José Jobson de Andrade Arruda, reside em São Paulo e é autor de textos didáticos desde 1976. 0 livro de sua autoria "Toda a História", destinado ao público do Ensino Médio encontrava-se, no final dos anos noventa, em sua $6^{\text {a }}$ edição, sendo um dos mais vendidos no país. Este foi 0 único de seus livros didáticos escritos em co-autoria, neste caso com o professor Nelson Piletti. No final dos anos noventa era professor titular da USP e vice-presidente da Fundação de Amparo a Pesquisa do Estado de São Paulo - FAPESP.

Os professores Ricardo de Moura Faria e Flávio Costa Berutti residem em Belo Horizonte e trabalham com livros didáticos desde, respectivamente, 1975 e 1986, sendo que as coleções "História: os caminhos do homem" para as quatro últimas séries do Ensino Fundamental e "História", para o Ensino Médio, estavam, no final dos anos noventa, entre as primeiras coleções didáticas mais vendidas no Brasil. Boa parte dos textos didáticos desses autores contou com a co-autoria do Prof. Adhemar Martins Marques. Desde meados dos anos oitenta o Prof. Ricardo é professor do Departamento de História da Faculdade de Filosofia, Ciências e Letras. de Belo Horizonte - FAFI-BH, atual UNI-BH. 0 Prof. Flávio, no final dos anos noventa, era professor de História na FAFI-BH e apoiava a divulgação de suas coleções didáticas junto à Editora Lê. 


\section{Formação escolar e acadêmica}

Os autores analisados são formados em História, fato que marca uma diferença importante de boa parte dos autores de livros didáticos da primeira metade do século que, em sua maioria, eram provenientes de outras áreas de saber, mesmo porque as licenciaturas só começaram a existir de maneira mais efetiva a partir dos anos trinta.

A Prof ${ }^{a}$. Joana Neves relatou o seguinte:

Eu fiz o primário, em uma escola particular, da colônia lituana, em São Paulo, [...] 0 primeiro ano do ginásio fiz em um ginásio particular, [...] porque eu quis fazer o ginásio imediatamente após o término do primário, não quis fazer um ano de admissão. [...] Depois, quando o Jânio Quadros era governador de São Paulo e baixou um decreto determinando que todos os grupos escolares funcionassem como ginásios noturnos, eu consegui transferii-me para um ginásio público [...]. Eu terminei o ginásio em 1958. Em seguida, fui para o colégio, também um colégio público chamado Presidente Roosevelt, seção do Ipiranga [...]. A Secretaria de Educação considerou meio esquisito existir uma instituição somente com o colegial e anexou esse colégio ao Instituto de Educação Alexandre de Gusmão. 0 meu certificado de conclusão de curso é do Instituto de Educação Alexandre de Gusmão, mas, eu estudei no Colégio Estadual Presidente Roosevelt e terminei em 1961, que foi 0 ano da LDB. [...] Eu fiz o vestibular em seguida. [...] Fiz o vestibular antigo também, que era o vestibular específico para o curso, com uma prova escrita e uma prova oral, com eliminação por disciplina. A exigência era que você tinha que ter média, no mínimo 4, por disciplina e no conjunto 5. Era um vestibular seletivo. Uns dois anos depois ele virou o vestibular classificatório, mas, eu ainda fiz o seletivo. [...] Eu fiz o Curso de História na USP, recebendo o diploma de Licenciatura e Bacharelado, embora isso não queira dizer grande coisa. 0 que a USP queria dizer com essa Licenciatura e Bacharelado é que você faz um conjunto de disciplinas no Departamento de História e, depois, você faz um conjunto de disciplinas pedagógicas na Faculdade de Educação. Eles conferem os dois diplomas, sendo que um condiciona o outro. Eles não dão 0 diploma só de Bacharelado, você tem que fazer Licenciatura também. [...] A graduação eu terminei em 1965. Eu comecei a fazer o Mestrado em História em 
1968, com a professora Emília Viotti da Costa, que depois foi cassada, afastada e eu também desisti da pós-graduação. Voltei em 1973, mas por conta dos meus compromissos com ensino, na Universidade onde eu trabalhava, em Aquidauana, em Mato Grosso, que não dava afastamento, eu acabei interrompendo, atrasando um pouco. Só quando eu fui para a Paraíba, que tinha um outro esquema de trabalho, $[. .$.$] um regime de tempo integral, de dedicação exclusiva, que implica$ que você tem que ter uma vaga para a pesquisa, foi que eu consegui terminar 0 Mestrado. Defendi o trabalho, senão me engano, em julho de 1981.[...] Eu comecei o Doutorado em seguida, o que foi um erro, por uma série de problemas que se eu fosse contar aqui alongaria demais essa entrevista, mas, também, não tem nada a ver com circunstâncias acadêmicas, foram problemas pessoais. Uma história de vida muito complicada e eu acabei não concluindo o Doutorado. Fiz os créditos, fiz a qualificação, mas, depois acabei não fazendo a tese. ${ }^{2}$

A formação acadêmica da professora Joana Neves assinala tanto uma formação em História como um contato com a Pedagogia, em uma instituição de ponta no Brasil que é a USP. Assinala também a realização do Mestrado e 0 impedimento em realizar seu doutorado. Vê-se, desde logo, o desenvolvimento de uma carreira acadêmica em paralelo à produção didática que, no caso da professora Joana Neves, teve início em 1975 e continua até os dias de hoje.

0 Prof. Jobson teve uma formação acadêmica bastante completa, mas, paralelamente, desenvolveu uma série de atividades vinculadas ao ensino de $2^{\circ}$ grau. Por conta disso, produziu, desde 1974, livros didáticos para esse nível de ensino. Somente em 1995, publicou uma coleção para $01^{\circ}$ grau. A seguir, ele relata seu processo de formação acadêmica:

A minha graduação foi no Departamento de História da Universidade de São Paulo, onde ingressei em 1963. [...] 0 que foi essencial durante minha graduação foi à experiência na cadeira de História Moderna e Contemporânea. Naquele momento, quando eu havia acabado de entrar na Universidade, houve o golpe de 64, aí nós entramos em um período de exceção que foi muito difícil. Neste momento, na Universidade, a intelectualidade, os professores, os estudantes eram, de maneira

${ }^{2}$ Joana NEVES. Entrevistas. p. 33-35. 
geral, todos de esquerda. Era difícil encontrar pessoas de direita - havia -- só que as pessoas de direita estavam um pouco, digamos, recônditas, escondidas, mas passaram a se manifestar depois do golpe de 64, sobretudo após 1968, quando a coisa enrijeceu. Muitas destas pessoas foram "dedos-duros", ou seja, foram pessoas que passaram a delatar seus colegas e que antes de 68 tinham uma atitude um pouco contemporizadora - aceitavam aqueles que tinham uma diferença que professavam uma posição de esquerda. Eu me integrava ao grupo que na época era considerado o grupo mais à esquerda do Departamento de História. [...] A cadeira de História Modema e Contemporânea tinha um grande prof́essor que era um [...] intelectual de excelente nível que é o professor Eduardo de Oliveira França. Existiam também alguns professores que pontificavam [...] . O principal professor, a principal referência intelectual do grupo era o Prof. Fennando A. Novais. [...] em relação ao Mestrado, o que acontece é o seguinte. Não havia naquela época esse Mestrado e esse Doutorado que nós conhecemos hoje. Isso é o que nós chamamos hoje, novo estilo, havia um velho estilo. 0 velho estilo significava o seguinte, a pessoa fazia doutoramento direto. Para isso ele fazia duas provas subsidiárias, a prova subsidiária seria o que corresponde hoje à qualificação. Só que era uma coisa assim: Você, perante uma banca constituída de três pessoas, submetia-se a uma prova oral com uma fundamentação escrita em que você fazia uma tese. Essas provas subsidiárias nomalmente eram para qualificá-lo para o doutoramento. Eu fiz aquilo que se chamava doutoramento direto. Eu escrevi a tese em 72 , ela foi defendida no início de 73, mesmo ano em que Fernando Novais, que tinha sido meu professor, defendeu a tese dele. 0 Novais também defendeu em 73, só que ele já era um professor reconhecidíssimo nessa altura e ele, inclusive, esteve na minha banca. Quando a tese foi escrita, aliás, uma das coisas que nos apressou, tanto eu quanto o Novais, era o fato de que ou a fazíamos naquele momento ou então teríamos que entrar no sistema novo. Entrar no sistema novo significava o seguinte: nós teríamos que nos tornar alunos de um curso de pós-graduação. Essa foi uma das coisas que nos apressou para fazer a tese no ano de 72. [...] então eu fiz doutoramento direto, com a minha tese que se chama "Portugal e Brasil na Crise do Antigo Sistema Colonial", escrita em 72. Ela foi escrita em um ano, ou melhor, em exatos 65 dias, mas, apesar disso ela tem quase 700 páginas. Ela foi publicada pela Áica em 1980, é o volume 64 da Coleção Ensaios. Esse foi o meu Doutoramento, essa foi a minha pósgraduação. É claro que eu tinha um orientador formal que era o Professor França, 
mas o professor França era um homem de História da Cultura, portanto ele está mais atualizado do que ninguém hoje, porque a História é assim - o mundo dá voltas. [...] 0 professor França ficou longamente, digamos, fora da grande corrente, porque a História era a econômica, era o Marxismo etc. 0 Prof. França volta a vida, e nós queéramos, digamos, os epígonos dos anos 60 e 70 entramos num período de eclipse, quando a chamada Nova História ou História da Cultura se desenvolveu. Mas essas coisas são cíclicas, isso significa que se vivermos mais uns 20 anos, quem sabe não pegaremos de novo a roda da História embarcando numa Nova História. ${ }^{3}$

A formação do Prof. Jobson assinala sua vinculação à temática da História Moderna e Contemporânea, que foi a área em que publicou seu primeiro livro didático, em 1974. À semelhança da Prof. Joana Neves, teve sua formação universitária e sua pós-graduação realizada na USP, convivendo com diversos historiadores renomados do país.

Os professores Ricardo e Flávio realizaram seus estudos universitários em Belo Horizonte, Minas Gerais. 0 Prof. Ricardo nos relatou o seguinte:

Sou formado em História (bacharelado e licenciatura) pela Universidade Federal de Minas Gerais, desde 1973. Fiz Especialização na Católica, no PREPES, em História Moderna e Contemporânea, no período de 1986 a 1988. Fiz, também, alguns cursos extras, tais como técnicas de pesquisa etc., enquanto era aluno. ${ }^{4}$

0 Prof. Flávio teve a seguinte formação acadêmica Licenciado em História pela UFMG, com Especialização em Metodologia da História pela $P U C-M G{ }^{5}$

Ambos são egressos da Universidade Federal de Minas Gerais - UFMG que é uma das grandes universidades brasileiras e que tem tradição tanto no ensino quanto na pesquisa histórica.

De fato, os quatro autores entrevistados são formados em História e tiveram envolvimento com estudos de pós-graduação nesta área. 0 Prof. Jobson foi o único que fez o Doutorado. Os outros autores, por uma série de razões,

\footnotetext{
3 José Jobson de Andrade ARRUDA. Entrevistas. p. 64-67.

${ }^{4}$ Ricardo de Moura FARIA \& Flávio Costa BERUTTI. Entrevistas. p. 118.

${ }^{5}$ Ibidem. p. 125.
} 
acabaram permanecendo vinculados à área de História, mas realizando outras atividades. Este fato nos parece interessante, pois existe um preconceito na área acadêmica no qual se considera que os autores de livros didáticos são intelectuais de menor envergadura.

\section{Trinerários profissionais}

Diferentemente dos autores de manuais escolares da primeira metade do século, os autores entrevistados tiveram larga experiência docente. A Prof ${ }^{2}$. Joana e o Prof. Jobson lecionaram para o então chamado $2^{\circ}$ grau, em situaçóes bastante diferenciadas. 0 Prof. Ricardo lecionou para o $1^{\circ}$ e $2^{\circ}$ graus durante muitos anos. $\mathrm{Na}$ época das entrevistas, todos estavam vinculados ao ensino superior e à área de História. Os professores Joana e Jobson atuavam na pósgraduação e os professores Ricardo e Flávio na graduação.

Os îinerários profissionais da Profa. Joana e da Profa. Elza Nadai, sua coautora, foram muito parecidos até o final dos anos sessenta, como nos diz a Profa. Joana:

Logo depois de formadas, nós duas [...] fomos trabalhar no Sistema de Ensino Vocacional, em São Paulo. [...] Nos cinco anos em que nós trabalhamos seguimos o seguinte itinerário: a Elza começou em Rio Claro e eu comecei em Barretos, depois ela foi para São Paulo, trabalhar como supervisora na área de Estudos Sociais e eu fui para São Paulo, trabalhar em um colégio que estava se iniciando. [...] 0 Sistema de Ensino Vocacional era um sistema oficial da Secretaria de Educação que, como o nome indica, não era profissionalizante, mais vocacionalizante, quer dizer, direcionava o ensino para fazer o aluno descobrir as suas habilidades e as suas competências indicativas para uma possível profissionalização e que pressupunha uma certa valorização do trabalho, do trabalhador, uma visão, digamos, mais social do trabalho. [...] 0 vocaciona! significava a própria formação pedagógica, na forma em que hoje a literatura fala em formação continuada, educação permanente e, o que é melhor, tinha um sistema de trabalho que permitia que o professor fosse construtor de conhecimento em sala de aula, exercendo uma certa autonomia intelectual, porque nós trabalhávamos em tempo integral. Eu vou dar os números da área de Estudos 
Sociais: o ensino era por área, trabalhávamos com o professor de Geografia. Os professores de Geografia e de História davam a mesma aula, com saídas para propostas holísticas, pois acontecia uma integração em um número menor de aulas no Vocacional. Freqüentemente, participavam das aulas de História e Geografia, os professores de Educação Musical, de Artes Plásticas, de Teatro e viceversa. 0 professor de Estudos Sociais participava das outras aulas, quando a discussão do tema exigia essa multiplicidade de olhar. Isto no antigo ginásio, de $5^{\mathrm{a}}$ à $8^{\mathrm{a}}$ série. Eu trabalhei sempre com $7^{\mathrm{a}} \mathrm{e} 8^{\mathrm{a}}$ séries e depois no colegial. 0 tempo integral permitia que você elaborasse suas aulas, seus conteúdos. [...] Eu tinha tempo integral, ganhava por 42 aulas[...] [Meu] trabalho era em tempo integral, na mesma escola, mas eu tinha 4 turmas, duas de $7^{\mathrm{a}}$ série e duas de $8^{\mathrm{a}}-3^{\mathrm{a}}$ e $4^{\mathrm{a}}$ naquele tempo - e não tinha mais do que 30 alunos por classe, com 4 aulas por semana. Dezesseis aulas, que eu partilhava com o professor de Geografia, com 120 alunos. Nessa condição o professor pode assumir sua autonomia intelectual, porque ele tem tempo para ler a bibliografia que ele não leu na graduação. [...] Nós trabalhávamos em conjunto com o pessoal da Pedagogia, que exercia a função de orientação educacional, trabalhando mais diretamente com os alunos e a orientação pedagógica, trabalhando mais diretamente com os professores. Nesses momentos, eu tinha verdadeiros cursos de Pedagogia, bem direcionados para as nossas necessidades específicas, porque eles decorriam daquilo que a gente sentia. Fazíamos, então, leituras, seminários e mantínhamos contato com pessoal da mesma área etc. [...] Nós tínhamos, em São Paulo, a cada começo de ano um planejamento longo, que durava mais de um mês, durante o qual tínhamos seminários etc. Eu me lembro, por exemplo, de ter participado de seminários com a Isaura Pereira de Queiroz, com o Antônio Cândido, com o Florestan Fernandes, para discutir interdisciplinalidade, o papel educativo da ciência e da pedagogia. [...] Eu sempre me considerei muito feliz por esta possibilidade profissional e a minha grande frustração foi não ter encerrado a minha carreira nessa experiência, o que aconteceu por causa da Ditadura, porque aí veio o Al-5, que fechou as escolas experimentais, impossibilitou as escolas experimentais. Eu tive colegas que foram presos [...]. Este espaço de atuação profissional acabou e não foi reeditado em nenhum outro lugar, no sentido de reproduzir aquelas condições, quer dizer tempo integral; possibilidade de trabalho em equipe[...]. A formação da Elza foi exatamente a mesma, passando pelos mesmos períodos, pelos mesmos 
percalços. Ela também foi para o ensino superior porque esse espaço foi fechado no secundário. Nossa experiência durou de 1966 a 1970. Mas, nesse momento, o trabatho já era vigiadíssimo. O nosso material já era vigiado, a escola uma vez chegou a ser fechada pela polícia que entrevistou os professores. ${ }^{6}$

A professora Joana Neves, nesta época, migrou do secundário para o ensino superior, no qual permaneceu até sua aposentadoria em 1995. As razões que a levaram a aposentadoria aparecem no texto abaixo:

Eu comecei a trabalhar em 1966 e pretendia chegar aos 30 anos de trabalho. A minha pretensão era de me aposentar em 1996, mas, a morte da prof́essora Elza Nadai precipitou minha aposentadoria. Eu tinha uma série de planos com ela, para ocupar esse meu último ano na ativa. Depois que ela morreu, então eu tinha que me reestruturar?

Mas a aposentadoria não parece ter significado para a Prof . Joana um abandono de suas vinculações com o meio acadêmico, pois deu continuidade aos empreendimentos de pesquisa na universidade e manteve-se ocupada com as reelaborações de suas coleções didáticas. Depreende-se, no relato da Prof ${ }^{a}$. Joana, uma inclinação para o envolvimento em atividades de investigação no campo do Ensino de História, o que Ihe cria dificuldades, pois não tem o título de Doutora.

0 Prof. Jobson teve um itinerário profissional vinculado tanto à carreira acadêmica quanto ao exercício do magistério do chamado à época $2^{\circ} \mathrm{grau}$, especialmente nos cursinhos preparatórios para o vestibular classificatório que davam acesso ao $3^{\circ}$ grau, como relatado a seguir.

Assim que eu terminei a graduação, fui escolhido pelo grupo [de História Moderna e Contemporânea da USP], pois naquela época não havia seleção para ingresso, havia escolha. O professor França tinha uma postura democrática em relação a isso, porque ele poderia indicar um assistente, mas ele não fazia isso, ele reunia

\footnotetext{
${ }^{6}$ Joana NEVES. op. cit. p. 41-44.

7 Ibidem. p. 36-37.
} 
a cadeira - o grupo, e dizia: - Quem vocês acham que deve ser? Ele podia até ter suas próprias opções, mas a pessoa que fosse indicada pelo grupo não podia ter bola preta, ou seja, se alguém dissesse: "- Eu não gostaria que fosse esse, estava vetado, não entrava. A razão é que o França achava que era fundamenta" haver diálogo dentro da cadeira de História Moderna e Contemporânea, era preciso que a pessoa fosse não só um intelectual competente, uma pessoa com possibilidades, com futuro, mas que fosse uma pessoa com possibilidades de convivência, uma pessoa com um certo padrão de sociabilidade, que pudesse se integrar, conversar com os colegas, que não se transformasse numa ilha dentro do departamento. Hoje nós temos um departamento onde as pessoas são praticamente todas catedráticas. 0 resultado disso é que as pessoas tornam-se ilhas e as relações são muito fortuitas. 0 França tinha um grupo e ele fazia questão que fosse de fato um grupo. Então, eu fui escolhido para ser assistente logo que terminei a graduação. Aliás, naquela época, a escolha era pelo catedrático, que dava um contrato temporário para você. Hoje nós fazemos concursos. [...] De um lado, nós tínhamos na época uma desvantagem, pois quando o catedrático era de baixo nível, era péssimo, ele só escolhia pessoas ruins, escolhia com critérios que muitas vezes eram falaciosos, escolhia pessoas ruins porque ele não queria "sombra", então ele não queria pessoas muito competentes ao lado dele. 0 professor França era um excepcional catedrático, de alta competência. [...] Eu fui escolhido pelo professor Fernando A. Novais, pelo professor França e, naquela época, fazia parte da cadeira também o professor Carlos Guilherme Mota. Este grupo me escolheu e foi a esse grupo que eu me filiei. Então as experiências que eu tive nesse período, as influências que eu tive, foram as experiências desse grupo. A bibliografia que nessa época nós líamos e dávamos aos alunos era a bibliografia clássica da intelectualidade nesse período, era uma bibliografia marxista. Então tivemos uma vasta experiência na leitura de textos marxistas, mas não éramos marxistas fechados, não era aquela coisa determinista, mecanicista, economicista, do econômico determinando o cultural, nada disso. Tanto que a cadeira dava como texto básico o texto do Maurice Dobb - "A Evolução do Capitalismo". Era o texto clássico que todos tinham que ler. Mas o texto que começava, por exemplo o Seminário que foi o primeiro curso que eu dei já no ano de 1967, chamava-se "0 Outono da Idade Média", do Huizinga, que é um clássico. Depois líamos o livro do Hauser, do Burckardt. Líamos e dávamos aos alunos. Então havia uma 
mesclagem de textos de História da Cultura, de História Religiosa e de História Econômica e Social. Lembro-me, por exemplo, que os textos do Marc Bloch e do Lucien Febvre eram indispensáveis. Quando eu terminei meu curso, eu sinto a satisfação de dizer que, naquela época, o critério era que o catedrático escolhia. Então eu fui convidado pelo professor Eurípedes Simões de Paula, que me convidou pessoalmente para ser assistente de História Antiga e Medieval. Isso aconteceu porque eu era um conhecido professor de História Antiga e Medieval nos cursinhos. Nesta época, eu já era um conhecido professor de Cursinho e tinha escrito várias apostilas, inclusive, eu as tenho até hoje. Elas eram coletâneas de textos que eu dava aos alunos. Euu tinha uma coletânea de textos em quatro volumes. Eu era professor, primeiro do Cursinho do Grêmio, que era um curso à esquerda, que deu origem ao Equipe Vestibular, eu fui um dos fundadores do Equipe Vestibulares, que foi uma divisão que saiu do Cursinho do Grêmio. 0 Cursinho do Grêmio terminou, mas o Equipe nasceu das entranhas do Cursinho do Grêmio, depois foi que eu passei para o Objetivo. 0 professor Eurípedes convidou-me para ser assistente dele, o professor França também. 0 Manuel Nunes Dias, que era 0 professor titular de História da América, fez uma sondagem, bem como a professora Nicia Vilela Luz que respondia, na época, pela cadeira de História do Brasil. Eu tive, portanto, convite de quatro cadeiras. Tenho a grande satisfação de dizer que eu pude escolher e acho que escolhi, na oportunidade, aquilo que batia com 0 meu horizonte intelectual e com as minhas opções de vida, sobretudo do ponto de vista da minha orientação intelectual e política. Tenho certeza que escolhi pelo melhor. Eu escolhi uma cadeira de escol que me amedrontava um pouco porque na época em que eu fui escolhido eu estava terminando a graduação, era o ano de 1966. Ora, eu nasci em 42, tinha exatos 24 anos e já estava dando aula no Departamento de História da Universidade de São Paulo, o que é um peso, uma responsabilidade enorme. É verdade que eu comecei dando apenas uns seminários e depois passei para os cursos teóricos, mas talvez eu tenha sido o professor mais jovem a assumir uma cadeira de História, uma responsabilidade no Departamento de História da USP. Diga-se de passagem que o França não dava contratos em definitivo. 0 dia em que ele me chamou ele disse-me: "- Jobson, estou dando a você um contrato, ele é temporário, e você vai provar que merece a renovação do contrato no desempenho das suas funções aqui dentro". Portanto, não existia esta coisa de que através do concurso se entra e se torna eterno, e mesmo que você 
depois não desenvolva bem as suas funções, você fica eternamente na função porque você é um concursado. Eu fui testado pelo França. 0 meu contrato foi renovado dois anos depois. Ele fez uma carta para o diretor: "- Solicito a recontratação do professor Jobson”, passou pelo departamento etc. Então houve um teste antes de decidir se eu seria ou não professor, se eu continuaria sendo professor do Departamento de História. ${ }^{8}$

Desde 0 início de sua formação em História, o Prof. Jobson teve vinculação com os cursinhos, começando no Técnicos, depois no preparatório do Grêmio da Faculdade de Filosofia, Ciências e Letras da USP, passando pelo Equipe Vestibulares e chegando ao Objetivo, no qual trabalhava com o colegial e 0 cursinho, ou seja, paralelamente à carreira acadêmica, ele desenvolveu uma carreira de professor de $2^{\circ}$ grau, experiência que, segundo ele, foi pré-condição para escrever livros didáticos. Mas, sua carreira acadêmica foi bastante profícua, conforme o relato a seguir do Prof. Jobson demonstra:

Eu comecei no Departamento de História dando aulas - na época existia uma divisão entre cursos teóricos, dados pelos professores mais antigos e os Seminários. No começo eu dava os Seminários. Os professores experientes, Fernando A. Novais etc., davam os cursos teóricos. Isso durou algum tempo, depois eu comecei a dar cursos teóricos. Os primeiros cursos foram sobre a Época Moderna, centrados, basicamente, na temática das revoluções no séc. XVII e no séc. XVIII e eu comecei a fechar, primeiro na Revolução Industrial e depois na Revolução Social do séc. XVII. Deste modo, a minha experiência na universidade é uma experiência que se concentrou em História Moderna e, portanto, trabalhando bastante com os temas sobre a transição do Feudalismo ao Capitalismo, a questão da Reforma, do Renascimento e, a partir daí, a questão das revoluções, sobretudo e primeiro na Revolução Industrial primeiro, na Revolução Francesa e depois voltando para a Revolução Inglesa de 1640, acabei me tornando um especialista em Revolução Inglesa de 1640, tanto que eu tenho uma tese de livre docência que acabou de ser publicada que se chama "A Grande Revolução Inglesa", que é exatamente a minha tese de docência que enlaça a Revolução Inglesa e Revolução Industrial,

${ }^{8}$ José Jobson de Andrade ARRUDA. op. cit. p. 65-67. 
mostrando que não é possível separar esses dois momentos da História da Inglaterra e que a historiografia inglesa geralmente divide, ela separa a Revolução Inglesa de Revolução Industrial. Esse livro que eu escrevi, esta tese, foi o resultado das minhas experiências como professor durante muitos anos de História da Época Moderna, sobretudo da Inglaterra. Essa é a experiência no campo didático, digamos, na área de graduação, depois também há a experiência de pós-graduação. [...] Eu sou professor de pós-graduação também, tenho um número muito grande de orientandos que deve estar chegando aí pela casa dos 30 que já defenderam doutoramento, em uma espécie de mapa do Brasil. Eu fui uma das primeiras pessoas a abrir a pós-graduação da USP com os professores das Universidades Federais. Por isso, eu tenho pessoas que fizeram tese comigo no Rio, na Bahia, em Pernambuco, no Maranhão, de todos lugares. [...] Ao mesmo tempo em que me tornei professor da Universidade de São Paulo, aliás antes disso, eu já era professor de Cursinho. Eu comecei a ser professor de Cursinho no $2^{\circ}$ ano da Faculdade, comecei a dar aulas num curso chamado Técnicos que ficava na Rua da Consolação e dei aula no curso André Dreyfuss e me tornei um professor mais conhecido no Cursinho do Grêmio da Faculdade de Filosofia (da USP) e depois passei para o Equipe Vestibulares e fui contratado assim como uma coisa bombástica pelo Objetivo, no ano de 1969. [...] Sempre na área de História. [...] Eu ia misturando o curso teórico [...], com a análise do documento, de tal maneira que eu fiz uma mixagem entre documento, bibliografia e síntese. Eu tenho um livro que se chama História Antiga e Medieval, publicado pela Ática, esse livro tem 18 edições hoje, esse livro, até parafraseando o Magri, até hoje é um livro "imexível". Ele é um clássico que circula desde os bons colegiais até as faculdades que o utilizam, sobretudo as faculdades particulares e outras. É um texto que as pessoas usam e muitas das interpretações que estão ali são absolutamente originais porque elas são calcadas num misto de bibliografia com documentos e com numerosas sínteses repetidas junto com os alunos, porque algumas dessas aulas eu devo ter dado centenas de vezes. [...] A principal preocupação era arranjar um vocabulário através do qual eu pudesse chegar à cabeça deles e por isso eu procurava ter a maior vivência possível de todas as coisas que passam pelo universo deles, fosse pelas novelas, fosse pelos filmes, fosse pelo que fosse, pelos livros. Eu continuo a fazer isso até hoje. Uma das coisas que eu leio mais depressa é a Folhateen. É uma maneira de saber qual é o vocabulário que eles estão usando 
etc., para poder entrar senão você não entra. [...] Eu comecei a dar aula em Cursinho, como disse a você, entrei em 63 na USP, no final de 64 eu já passei a dar aula no Técnicos e daí disparei e não parei mais e do Cursinho eu passei a dar aula no colegial. Eu comecei a dar aula no colegial do Objetivo quando o Objetivo abriu o colegial, acho que no ano de 71 , faziam dois anos que eu estava no Objetivo. Então desde 71 eu tenho experiência em aulas em colegial e aulas de Cursinho, sem parar, até me tornar professor titular da USP. [...] Eu acho que eu sou, na área de Ciências Humanas, um dos poucos professores que chegou a professor titular com tempo parcial, nesse período de tempo e me foi fundamental, exatamente essa velocidade que eu aprendi. Aprender a ler com muita rapidez, a sintetizar rapidamente, a perceber rapidamente quais eram as idéias principais, isso eu aprendi muito dando aula. [...] eu era professor titular da Universidade de São Paulo, eu era professor de História Moderna, titular de História Moderna e eu dava aula, me tornei professor titular no ano de 86, quando eu fiz concurso para Professor Titular. Nesse mesmo ano, eu me tornei chefe do Departamento de História. Foi nesse momento que eu tive que pedir tempo integral na Universidade, porque o chefe do departamento tem que ter tempo integral. Eu pedi o tempo integral nessa oportunidade, portanto só em 86. [...] Eu fiquei de 1967 a 1986, dezenove anos na USP com tempo parcial e fiz a carreira nesse período, mas ai isso se tornava incompatível com aulas, então, nesse momento, eu parei de dar aulas no secundário, não dei mais aulas diretamente em sala de aula, andei ainda dando umas conferências, assim de final de semana, que eram monstruosas, tinham 600, 700 alunos [...] Tem uma coisa que eu preciso dizer para você, eu fui o primeiro "ibope" do Objetivo durante o tempo em que estive lá. Tá certo? Eu dava aula para 600 alunos, 700 alunos, dava aula no teatro. ${ }^{9}$

0 relato do Prof. Jobson deixa claro que seu envolvimento simultâneo com a universidade e o ensino secundário trouxe-lhe uma formação muito especial, pois, permitiu-lhe um contato tanto com o conhecimento científico de ponta como com a prática pedagógica desenvolvida nos cursinhos. Mas, segundo ele, esse foi um dos fatores fundamentais para escrever livros didáticos:

\footnotetext{
${ }^{9}$ Ibidem. pp. 67-71.
} 
[...] sabe quantas salas eu tinha no Objetivo? 80. Sabe quantos alunos tinha por sala nos bons tempos? Em torno de 400. [...] Ora, eu dava aula para 400 alunos, garotos de 17 anos, 18 anos e você não ouvia um ruído, você não via uma mosca na sala e havia alunos que assistiam 2, 3, 4 vezes a mesma aula. Bom, então você imagina que uma pessoa que faz uma coisa dessas, ele repete muitas vezes a aula, a matéria entra de tal maneira na cabeça que a hora em que eu me decidi a escrever um livro, eu não fazia consultas, ia direto, quer dizer, as grandes interpretações estavam todas prontas porque eu tinha "masserado" essas grandes interpretações. [...] eu tinha uma síntese que era original. Para escrever um texto como é que você faz? Você lê um documento, dois, três, ai você tem uma idéia, você lê a bibliografia, confronta documentos/bibliografia, só que eu fiz isso o tempo todo. É que eu não tenho aqui, acho que está lá no sítio, lá na fazenda, a coletânea de documentos que eu tenho, eu decorei aqueles documentos, decorei, de tantas vezes que eu repeti aqueles documentos. ${ }^{10}$

Há nesse relato vários elementos importantes. Primeiro, o fato da experiência de sala de aula ser considerada decisiva pelo autor para a produção de seus textos didáticos e mesmo para a produção de suas teses acadêmicas. Segundo, a afirmação do Prof. Jobson de que seus livros didáticos foram escritos sobre temas de sua área de especialização acadêmica, exaustivamente trabalhados nas aulas ministradas na Universidade e, principalmente, nas muitas aulas ministradas no cursinho e no $2^{\circ}$ grau.

0 itinerário profissional dos professores Ricardo e Flávio assinala que ambos tiveram larga experiência no magistério de $1^{\circ}$ e $2^{\circ}$ graus. A relação de ambos com o ensino de $3^{\circ}$ grau esteve vinculada a FAFI-BH, na qual trabalham desde os anos oitenta. De qualquer modo, ambos assinalaram, na entrevista, que consideram fundamental à vinculação com a realidade dos níveis de ensino para os quais escrevem seus textos didáticos.

0 exame dos currículos desses autores evidencia algumas diferenças substanciais quanto ao trabalho acadêmico de cada um deles, fato este que poderá ajudar a entender o nível de envolvimento de cada um com suas coleções didáticas.

${ }^{10}$ Ibidem. p. $72-74$. 
A Proff ${ }^{a}$. Joana Neves trabalhou na Universidade Estadual de Mato Grosso/ Centro Pedagógico de Aquidauana (transformados em Universidade Federal de Mato Grosso do Sul - UFMS/Centro Universitário de Aquidauana, entre 1971 e 10,77) e, depois, na Universidade Federal da Paraíba, entre 1978 a 1995. Nesse período, lecionou diversas disciplinas na área de História, tais como: Introdução aos Estudos Históricos, História do Brasil, Prática do Ensino de Estudos Sociais e Teoria da Ciência Histórica. Participou de três comissões do Departamento de História da UFPB. Orientou e levou a defesa cinco monografias de Especialização e duas dissertações de Mestrado. Desenvolvia, no final dos anos noventa, pesquisas no Núcleo de Documentação e Informação Histórico Regional - NDIHR/UFPB, desde 1978. Exerceu nove cargos de chefia ou direção, desde 1974. Prestou onze assessorias técnicas desde 1979, entre as quais, foi parecerista para o MEC/SEF no processo de análise dos Parâmetros Curriculares Nacionais, para $1^{\mathrm{a}}$ à $4^{\mathrm{a}}$ séries do Ensino Fundamental, em 1996. Participou de quatro bancas de qualificação e três de defesa de Mestrado. Ministrou uma série de outros cursos vinculados à área de História. Apresentou mais de uma centena de trabalhos em congressos ou similares, nas quais fez comunicações, palestras, participou de mesas redondas etc. Defendeu sua Dissertaçã்o de Mestrado, intitulada "A Fundação de Aquidauana e a Ocupação do Pantanal: civilização e dependência", em 1981, no Departamento de História da USP. Escreveu uma série de livros didáticos, dois capítulos de livros e, em coautoria, dois documentos para a Secretaria de Educação do Estado de São Paulo, respectivamente em 1975 e 1986. Resenhou e introduziu sete trabalhos. Publicou dez artigos em periódicos nacionais. Pertence à Associação Nacional de História - ANPUH, a Associação dos Docentes da UFPB - Seção Sindical ADUFPB/JP e ao Sindicato Nacional de Docentes das Instituições de Ensino Superior - ANDES/SN. Em todos exerceu cargos importantes ao longo de seu exercício profissional. Teve, também, intensa participação em eventos políticosindicais, desde 1988.

0 Prof. Jobson é Doutor em História, tendo defendido a Tese: "0 Brasil no Comércio Colonial (1796-1808): contribuição ao estudo quantitativo da economia colonial", em 1973, na USP. Sua Tese de Livre-Docência intitulouse "As raízes do Industrialismo Moderno; estudo histórico sobre as origens da Revolução Industrial na Inglaterra", em 1982, na USP. Exerceu um total de 37 
cargos e funções distribuídos entre a USP (a maioria), CNPq, FAPESP, entre outros. Emitiu cerca de oito pareceres para projetos e congêneres Publicou mais de sessenta textos em editoras nacionais e internacionais, em que se incluem resenhas, artigos, livros didáticos e livros de História. Publicou também 44 textos na imprensa periódica, tais como na Folha de S.Paulo, no Jornal da Tarde, na Gazeta Mercantil etc. Tem no prelo cinco livros pela Editora Ática, entre os quais um sobre Christopher Hill. Proferiu 33 conferências. Participou, de mais de uma centena de simpósios e seminários, nacionais e internacionais. Fez inúmeras comunicações e palestras. Participou de diversas mesas-redondas. Ministrou mais do que três dezenas de cursos para graduação e pós-graduação. Participou de quase uma centena de bancas de examinadoras de Mestrado, Doutorado e concursos. Atualmente, tem diversos orientados. Pertence a nove associações científicas, dentre as quais quatro nacionais e cinco internacionais.

0 Professor Ricardo é Especialista em História Moderna e Contemporânea, tendo cursado o PREPES da PUC-MG, entre 1986 e 1988. Fez mais de uma dezena de cursos, dos quais cinco voltados para a área de História. Teve aprovação em diversos concursos, dentre os quais o $1^{\circ}$ lugar no Concurso de Monografias do Departamento de História da Faculdade de Filosofia e Ciências Humanas - FAFICH da UFMG. Foi professor de História para o $1^{\circ} \mathrm{e} 2^{\circ}$ graus em diversas instituições públicas e privadas de Minas Gerais, de 1969 a 1991. Exerceu mais de uma dezena de cargos de chefia e coordenação desde 1969. Publicou cerca de quase duas dezenas de textos em diversos meios, jornais, revistas e anais de congressos. Escreveu sozinho ou em co-autoria 10 apostilas e mais de 23 livros didáticos, com mais de 12 coleções didáticas para $01^{\circ}$ e $2^{\circ}$ graus, bem como alguns textos paradidáticos. Participou de mais de duas dezenas de eventos científicos. Foi debatedor e palestrante em quase uma centena de eventos, muitos dos quais direcionados aos professores da rede pública e particular do ensino de $1^{\circ}$ e $2^{\circ}$ graus do Estado de Minas Gerais.

Com esses dados expostos, pode-se traçar um perfil desses autores. A Prof $^{a}$. Joana Neves sempre esteve muito próxima das questões ligadas às lutas dos professores universitários. Por isso mesmo, a presença de atividades ligadas aos sindicatos profissionais, sempre ocupou boa parte de seu tempo. Mesmo assim, ela desenvolveu uma série de atividades científicas, mas sem ter produzido trabalhos de grande impacto acadêmico, ainda que tenha conseguido defender 
sua Dissertação de Mestrado. Seu depoimento e seu currículo nos permitem afirmar que a produção de seus livros didáticos não exerceu centralidade em seu cotidiano profissional.

0 Prof. Jobson, visto por meio de sua fala e de seu currículo, deixa uma sensação de espanto, pois como é que ele teve tempo para desenvolver tantas atividades ligadas à área de História? De qualquer modo, percebe-se que tal como a Prof ${ }^{a}$. Joana, ele não conferia centralidade à suas coleções didáticas no seu trabalho diário. Pelo contrário, seu tempo estava dividido entre as atividades acadêmicas da universidade e as aulas no cursinho. Mesmo assim, ele conseguiu chegar à Livre-Docência e ocupar cargos importantes da área acadêmica, especialmente em São Paulo. Toda essa atividade não permitiu, como ele mesmo nos revelou, promover muitas alterações em seus livros didáticos. Só a partir de alguns anos ele se tem dedicado mais as suas coleções didáticas.

0 Prof. Ricardo, dentre estes autores, é o que teve menor formação acadêmica e produção científica, mas, diferentemente da Prof ${ }^{a}$. Joana e do Prof. Jobson foi o que mais produziu títulos de livros didáticos no período. Ao contrário daqueles autores, para ele o livro didático, especialmente, nas décadas de oitenta e noventa, ocuparam muito de seu tempo disponível. Inclusive, grande parte de seu currículo refere-se ao desenvolvimento de atividades vinculadas à divulgação das idéias e concepções históricas e pedagógicas presentes em seus livros didáticos. Com grande número de coleções no mercado, as necessidades de revisão e atualização sempre foram enormes.

Os autores que estão sob nossa análise tiveram percursos profissionais bastante diferenciados, mas todos eles mantiveram-se vinculados à área de História e mesmo à Educação. Suas coleções didáticas são bem posicionadas atualmente e eles são autores de livros didáticos bastante conhecidos e respeitados no meio escolar. 


\section{GRGML DA FACULDADE DE FLOSOFIA CIÉNCIAS I LETRAS}

U $\mathrm{S} P$

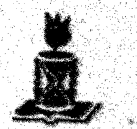

DEPARTAMENTO DE CURSOS

\section{Mistorta Antiga e Merdevil}

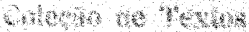

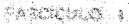

preparatórtos às faculdades de; Hlos ofla engenharit medicina agronomin economita arquiletura direlto

RUA HARTINICO FRAO 377 - FONE 51352

RUA ALEUOUERQUE LINS, 1345 - FONE 31.3635 PRACA DA LIAEROADE, go - 2. ANDAK SAO AULO

Figura 1-Capa de História Antiga e Medieval: coleção de textos, de autoria de José Jobson de Andrade Arruda, editada em 1966, pela USP, no formato 16x23. 


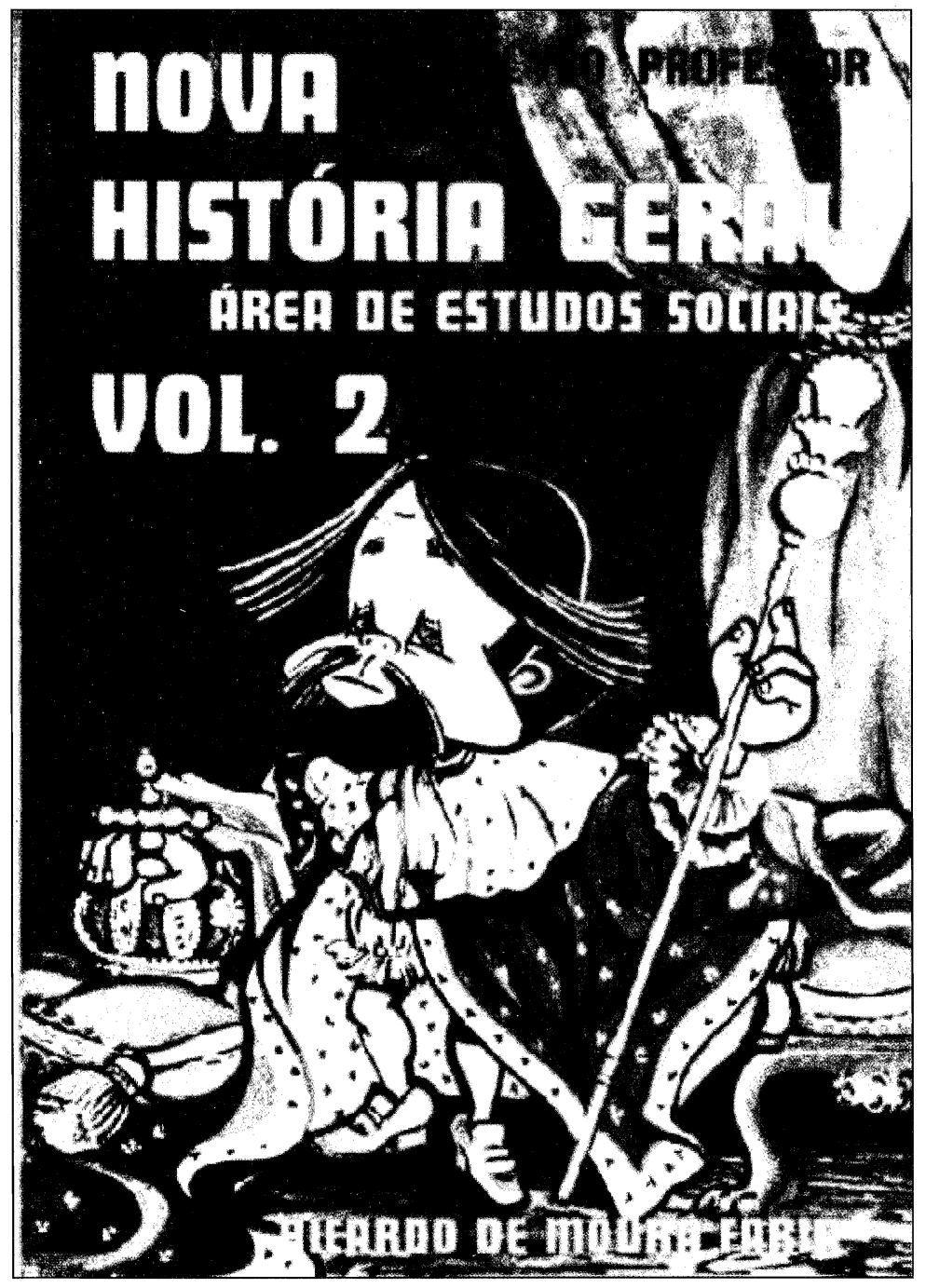

Figura 2 - Capa da $1^{a}$ edição do livro de Nova História Geral (vol. 2) de autoria de Ricardo de Moura Faria, publicado pela Editora Lê em 1975, com 112 páginas e formato $14 \times 21$. 


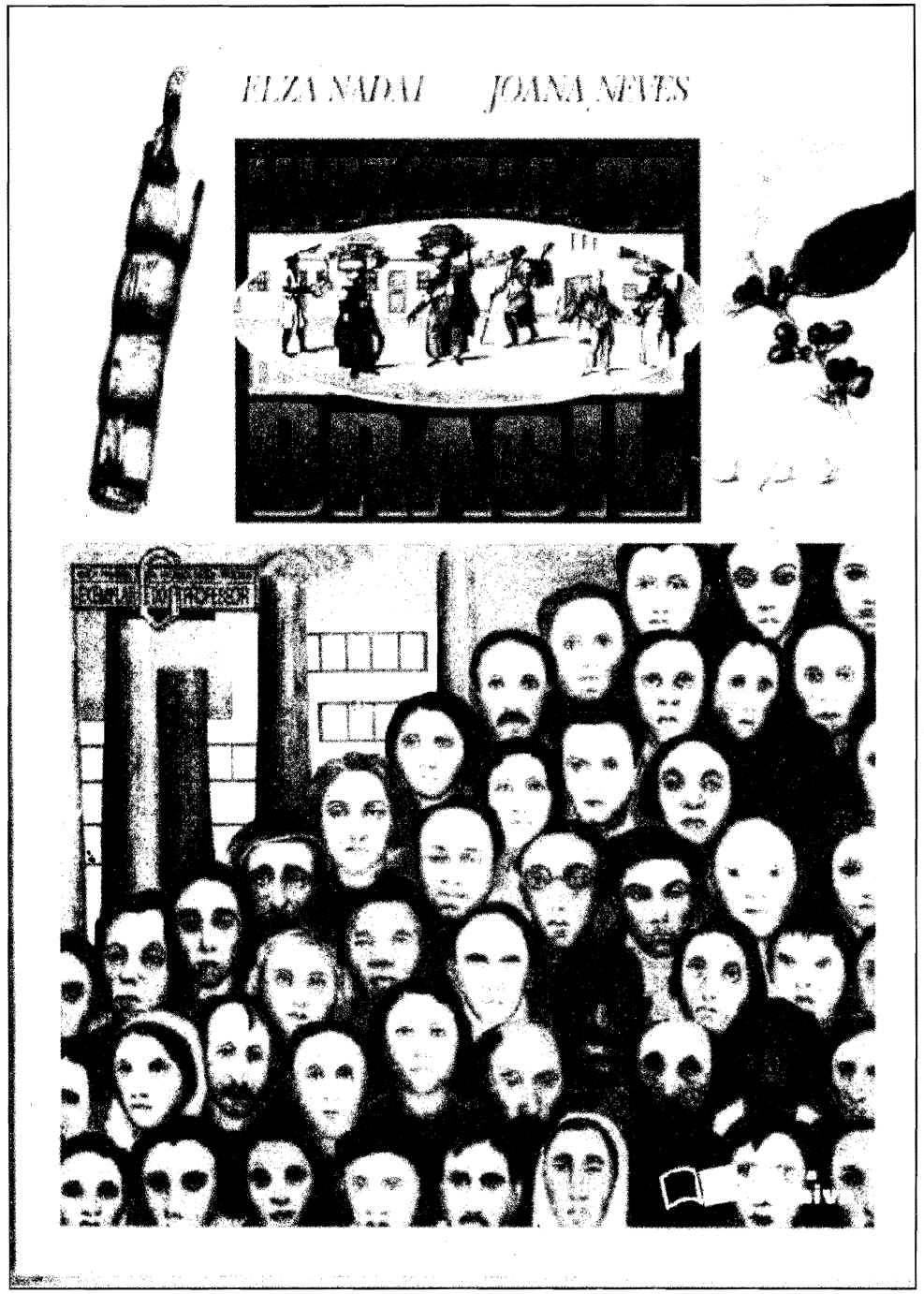

Figura 3 - Capa da $17^{\text {a }}$ edição do livro de História do Brasil de Joana Neves e Elza Nadai, publicado pela Saraiva, em 1995, no formato $17 \times 24$. 


\section{Histórico da Produção de Livros Didáticos}

A Profia . Joana Neves está envolvida com a produção de textos didáticos desde 1975, sendo que todas seus livros e coleções didáticas foram publicados pela Editora Saraiva. Estes sofreram constantes revisões e atualizações. A versão mais duradoura, por exemplo, do livro de História da América foi a elaborada em 1982. 0 livro de História Geral: Moderna e Contemporânea e de História do Brasil são os que mais demandaram atualizações, que, nesse caso, são muitas vezes complementações. Existe, de fato, uma corrida contra o tempo das editoras e autores para colocarem no mercado esses livros o mais atualizados possível, fato que confere aos capítulos finais um tom próximo do jornalismo, pois a interpretação dos eventos ocorridos no tempo imediato, quase sempre, não são 0 resultado de uma análise cuidadosa das reais motivações e implicações dos mesmos na realidade social.

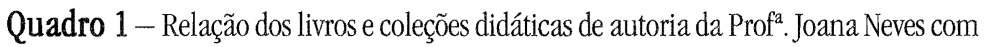
a descrição dos co-autores, destinatário e período de vigência no mercado (1978-1998).

\begin{tabular}{|c|c|c|c|}
\hline Título & Autores & Destinatário & Período no mercado" \\
\hline Estudos Sociais & Joana Neves, Elza Nadai e Suria Abucarma & $5^{2}$ e $6^{2}$ séries do $1^{0}$ grau & 6 anos $(1978 / 1984)$ \\
\hline História da América & Joana Neves e Elza Nadai & $2^{\circ}$ gral & $17 \operatorname{anos}(1979 / 1996)$ \\
\hline História do Brasil & Joana Neves e Elza Nadai & $2^{\theta}$ grau & 18 anos (desde 1980) \\
\hline $\begin{array}{l}\text { História Moderna e } \\
\text { Contemporânea }\end{array}$ & Joana Neves e Elza Nadai & $2^{\circ}$ grau & 14 anos (desde 1984) \\
\hline História Antiga e Medieval & Joana Neves e Elza Nadai & $2^{\circ} \mathrm{grall}$ & 13 anos (descle 1985) \\
\hline História do Brasil & Joana Neves e Elza Nadai & $5^{a}$ e $6^{a}$ séries do $1^{0}$ gral & 11 anos $(1985 / 1996)$ \\
\hline
\end{tabular}

A vendagem dos livros e coleções didáticas da Profa . Joana sempre foi relativamente baixa, se comparada com a de outros autores da mesma área e da mesma editora, o que assinala que alguns livros que são considerados muito bons pelos analistas do livro didático, especialmente pelos acadêmicos, revelam baixo desempenho de vendas junto ao mercado consumidor, ou seja, não são bem aceitos pelos usuários finais, que são professores a alunos espalhados por todo país. É sintomático que a avaliação das causas desse

\footnotetext{
${ }^{11} 0$ período em que as coleções estiveram no mercado deve ser entendido com certa flexibilidade, pois, se a data de início da produção é segura, a retirada do catálogo das editoras não coincide com o final das vendas nas lojas e utilização pelos professores. Há uma margem de pelo menos quatro ou cinco anos que deve ser levada em consideração.
} 
processo, feita pela Prof ${ }^{a}$. Joana Neves, considere que os motivos da não aceitação dos livros didáticos considerados bons pelos acadêmicos esteja vinculada à qualidade desses livros. Fica-nos evidente a diferença de critérios avaliativos dos analistas e dos usuários deste instrumento de ensino. As consequiências deste descompasso são perceptíveis, por exemplo, quando o MEC promoveu uma avaliação dos livros didáticos nacionais, na década de noventa, elaborando um guia em que classificava os livros como melhores ou piores, por meio de um sistema de estrelas, ou seja, quanto mais estrelado um livro melhor ele era e vice-versa. Acontece que as pessoas que promoveram esta avaliação eram na maioria acadêmicos que tinham uma visão diferente dos usuários do que seja qualidade dos livros didáticos. Estabelece-se, desse modo, uma situação paradoxal, em que os livros prestigiados, do ponto de vista da intelectualidade, não são utilizados pela maioria dos professores e alunos e os livros sem 0 prestígio dessa intelectualidade são sucessos de venda.

Profa. Joana Neves revelou conhecimento das questões ligadas a forma do livro didático, com conhecimento das possibilidades técnicas de conferir maior ou melhor qualidade ao livro, usando quatro cores e não duas, imprimindo bem as ilustrações etc. Revelou, também, o conhecimento dos limites de utilização desses recursos, ou seja, o quanto eles encarecem a produção dos didáticos. Quanto ao conteúdo de seus livros didáticos, Profa. Joana Neves esclareceu sobre o papel desempenhado pela censura estatal no desenvolvimento de suas obras e o quanto ela deixou que diversos temas fossem abordados criticamente e mesmo que alguns temas ocupassem espaço em suas obras. Isto evidencia que as pressões que levam a configuração de um determinado conteúdo disciplinar, especialmente em História, são provenientes de diversos lugares.

Segundo a Prof ${ }^{a}$. Joana Neves relatou, a entrada de novos temas e conteúdos ou mesmo ampliação de espaço para outros seguiu o itinerário da abertura política brasileira, que se consolidou a partir do início dos anos oitentą. 0 fato de tratar 64, como um golpe político-militar e não como uma Revolução, na História do Brasil, publicada em 1980, ilustra o quanto era difícil tratar das temáticas históricas naquela época, pois, foram necessários 16 anos para poder inserir nos livros escolares uma idéia como essa.

o Prof. Jobson está envolvido com a produção de textos didáticos desde 0 
final dos anos sessenta, mas a publicação de um livro para se utilizado nas escolas de $2^{\circ}$ grau só ocorreu em 1974. Prof. Jobson não tinha em seus planos escrever livros didáticos. Este é, inclusive, um aspecto interessante dá con dição de grande parte dos autores de livros didáticos de História. Muitos deles fizeram o Curso de História e até pós-graduação nessa área, porém, não tiveram qualquer treinamento ou aprendizado de como fazer livros didáticos. Sabe-se, no entanto, que muitos deles antes de escrever livros didáticos, haviam produzido apostilas, como é o caso do Prof. Jobson e do Prof. Ricardo. Estas apostilas, nestes casos, foram o germe das produções didáticas destes autores. Outro aspecío ressaltado pelo Prof. Jobson a semelhança de Prof ${ }^{2}$. Joana foi sobre a censura que foi uma sombra a pairar sobre sua produção didática. As obras didáticas do Prof. Jobson podem ser visualizadas no quadro a seguir:

Quadro 2 - Relação dos livros e coleções didáticas de autoria do Prof. José Jobson de Andrade Arruda com a descrição dos co-autores, destinatário e período de vigência no mercado (1974 - 1998).

\begin{tabular}{|c|c|c|c|}
\hline Título & Autores & Destinatário & Período no mercado \\
\hline História Moderna e Contemporânea & Jobson Arruda & $2^{\circ}$ grall & 24 anos (desde 1974 ) \\
\hline História Antiga e Medieval & Jobson Arruda & $2^{\circ} \mathrm{grau}$ & 22 anos (desde 1976$)$ \\
\hline Toda a História & $\begin{array}{l}\text { Jobson Arruda \& Nelson Piletti (redação } \\
\text { de Mylton Severiano da Silva) }\end{array}$ & $2^{\circ}$ grau & 3 anos (desde 1995) \\
\hline
\end{tabular}

As obras didáticas do Prof. Jobson voltavam-se prioritariamente para $02^{\circ}$ grau. Somente em 1995 ele escreveu uma coleção para $01^{\circ}$ grau. Todos os livros didáticos de autoria do Prof. Jobson foram publicados pela Ática. Ele possui algumas obras não-didáticas publicadas também pela Brasiliense e pela HUCITEC, versando, principalmente, sobre temáticas da História Moderna.

Nesse sentido, o Prof. Jobson se diferencia dos outros autores entrevistados, pois ao lado de sua produção didática, produziu algumas obras destinadas ao público especializado em História, ou seja, aos historiadores e estudiosos do período moderno.

É interessante observar que os textos didáticos produzidos pelo Prof. Jobson foram questionados na imprensa da época por suas vinculações marxistas. Naquela época, diversos intelectuais e militantes de esquerda que demonstrassem pendores para o marxismo, identificado pelos militares e órgão 
do governo como sinônimo de comunismo, corriam riscos enormes, seja sobre seu futuro profissional ou mesmo riscos de vida. De qualquer modo, o livro de História Moderna e Contemporânea publicado em 1974 era diferente dos livros até então existentes no mercado, tanto nos temas que passavam a ter relevância, como "A transição do feudalismo ao capitalismo", "As revoluções de 1830 e 1848", "A Revolução Russa", "A hegemonia americana" e "0 socialismo na União Soviética", como na inserção de conceitos e interpretações oriundas da tradição marxista. Conceitos como relaçoes sociais de produção, classe social, força de trabalho etc. eram os fios condutores da interpretação histórica contida neste livro.

As mudanças ocorridas no texto do História Moderna e Contemporânea, segundo o Prof. Jobson, foram provenientes de movimentos no campo historiográfico mais amplo, ou seja, as pesquisas históricas, especialmente as européias e norte-americanas, caminhavam para uma abordagem mais cultural em detrimento da econômica. 0 exame dos novos capítulos inseridos e da bibliografia incorporada ao texto, refletem, de fato, a inclusão de uma abordagem vinculada à História Cultural. A obra passa a ter uma certa duplicidade, pois alguns temas continuam a ser abordados pelo viés econômico e outros pelo cultural. Mas isso parece inevitável em qualquer obra que não seja monográfica, haja visto que é impossível tal unidade interpretativa.

Verifica-se, desse modo, que a constituição dos conteúdos dos livros didáticos também sofre pressões provenientes do desenvolvimento acadêmico da própria disciplina, das tendências de pesquisa e abordagem que aparecem nas obras historiográficas e que acabam impactando sobre os autores de livros didáticos. Nos livros do Prof. Jobson, as marcas de sua evolução são motivadas, menos por razões pedagógicas, do que pela influência das mudanças paradigmáticas no campo da História.

0 Prof. Ricardo está envolvido com a elaboração de textos didáticos desde meados dos anos setenta, tendo publicado seu primeiro livro didático em 1975, pela Editora Lê, à qual pertence até os dias de hoje. 0 Prof. Ricardo iniciou sua carreira de autor de livros didáticos de História por meio de uma coincidência de fatores, mas à semelhança do Prof. Jobson, ele também tinha muita experiência com ensino e havia produzido uma série de apostilas. No período compreendido entre 1970 e 1974, produziu dez apostilas para dois colégios de Belo Horizonte, nos quais lecionava. A partir de 1975 dedicou-se apenas às suas coleções didáticas publicadas pela Editora Lê. 
Aspecto interessante a ser considerado é que algumas das coleções didáticas escritas pelo Prof. Ricardo eram dirigidas às mesmas séries de ensino e permaneceram no mercado simultaneamente. 0 que explica isso, provavelmente é 0 fato de estes livros serem produzidos para o mercado nacional e este mercado ser bastante diferenciado; é possível ter produtos diferenciados para serem utilizados por clientes diferenciados. Há também uma constatação bastante simples, pois, uma vez que uma determinada turma iniciou à $5^{\text {a }}$ série, por exemplo, com o uso de um determinado livro, somente quando ela chegar à $8^{a}$ série deixará de usar os outros volumes de uma mesma coleção didática. Mas, como este convívio, às vezes, atingiu mais que dez anos, pode-se supor que 0 mercado tem condições de utilizar produtos diferenciados. Muitas vezes um livro considerado difícil pela maioria dos professores é utilizado por alguns, fato que assegura a continuidade da publicação de coleções que não atingiram o sucesso esperado entre a maioria dos professores.

Percebe-se, também, que o Prof. Ricardo e a Editora Lê, são velozes em atender às novas demandas criadas pelo mercado consumidor, sejam elas provenientes de mudanças curriculares estaduais ou nacionais ou de novas práticas pedagógicas em moda nas escolas. Percebe-se, por fim, que existe uma preocupação, especialmente nos últimos anos, em ocupar o máximo possível dos mercados existentes, com coleções que sejam adequadas principalmente às demandas do Estado de Minas Gerais, onde a editora está sediada, e às demandas nacionais, que atualmente estão centradas nas propostas do ensino integrado da História. As obras e coleções didáticas do Prof. Ricardo podem ser observadas no quadro a seguir: 
Quadro 3 - Relaçãa dos livros e coleções didáticas de autoria do Prof. Ricardo de Moura Faria com a descrição dos co-autores, destinatário e período de vigência no mercado (1975-1998).

\begin{tabular}{|c|c|c|c|}
\hline Título & Autores & Destinatário & Período no mercado \\
\hline Nova História Geral & Ricardo de Moura Faria & $7^{\mathrm{a}} \mathrm{e} 8^{\mathrm{a}}$ séries do $1^{0} \mathrm{grau}$ & 5 anos $(1975 / 1980)$ \\
\hline Fstudos Sociais & $\begin{array}{l}\text { Ricardo de Moura Faria, Antônio Marum, } \\
\text { Gleuso Damasceno Duarte e Tânia Maria } \\
\text { Guimarães }\end{array}$ & $5^{\mathrm{a}}$ à $8^{\mathrm{a}}$ séries do $1^{0}$ grau & 7 anos $(1975 / 1982)$ \\
\hline $\begin{array}{l}\text { Nova História } \\
\text { (integrado) }\end{array}$ & $\begin{array}{l}\text { Ricardo de Moura Faria \& Adhemar Martins } \\
\text { Marques }\end{array}$ & $2^{\circ}$ grau e Vestibulares & 11 anos $(1976 / 1987)$ \\
\hline $\begin{array}{l}\text { Nova Perspectiva em } \\
\text { Estudos Sociais } \\
\text { (para o mercado de São } \\
\text { Paulo) }\end{array}$ & $\begin{array}{l}\text { Ricardo de Moura Faria, Gleuso Damasceno } \\
\text { Duarte e Francisco Liberato Póvoa }\end{array}$ & $5^{a}$ e $6^{a}$ séries do $1^{0}$ grau & 4 anos $(1976 / 1980)$ \\
\hline Síntese de História & $\begin{array}{l}\text { Ricardo de Moura Faria \& Adhemar Martins } \\
\text { Marques }\end{array}$ & $5^{\mathrm{a}}$ à $8^{\mathrm{a}}$ séries do $1^{0}$ grau & 5 anos $(1979 / 1984)$ \\
\hline Nossa História & $\begin{array}{l}\text { Ricardo de Moura Faria \& Adhemar Martins } \\
\text { Marques }\end{array}$ & $5^{a}$ à $8^{a}$ séries do $1^{0}$ graul & 8 anos $(1983 / 1991)$ \\
\hline Construindo a História & $\begin{array}{l}\text { Ricardo de Moura Faria, Adhemar Martins } \\
\text { Marques e Flávio Costa Berutti }\end{array}$ & $5^{\mathrm{a}}$ à $8^{\mathrm{a}}$ séries do $1^{0}$ grau & 10 anos (1987 a 1997) \\
\hline $\begin{array}{l}\text { História } \\
\text { (integrado) }\end{array}$ & $\begin{array}{l}\text { Ricardo de Moura Faria, Adhemar Martins } \\
\text { Marques e Flávio Casta Berutti }\end{array}$ & 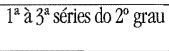 & 10 anos (desde 1987) \\
\hline $\begin{array}{l}\text { História: os caminhos do } \\
\text { homem }\end{array}$ & $\begin{array}{l}\text { Ricardo de Moura Faria, Adhemar Martins } \\
\text { Marques e Flávio Costa Berútti }\end{array}$ & $5^{\mathrm{a}}$ à $8^{\mathrm{a}}$ séries do $1^{0}$ grau & 7 anos (desde 1991) \\
\hline $\begin{array}{l}\text { Brasil: História em } \\
\text { construção }\end{array}$ & $\begin{array}{l}\text { Ricardo de Moura Faria, Adhemar Martins } \\
\text { Marques e Flávio Costa Berutti }\end{array}$ & $5^{a}$ à $8^{2}$ séries do $1^{0}$ grau & 2 anos (desde 1996) \\
\hline História Antiga e Medieval & $\begin{array}{l}\text { Ricardo de Moura Faria, Adhemar Martins } \\
\text { Marques e Flávio Costa Berutti }\end{array}$ & $2^{\circ}$ grau & 2 anos (desde 1996) \\
\hline
\end{tabular}

Entre os autores entrevistados, o Prof. Ricardo é, sem dúvida, o que mais obras e coleções didáticas teve publicadas, a maioria pela Editora Lế; mas houve duas obras publicadas pela Editora Contexto ${ }^{12}$. 0 Prof. Ricardo elaborou a maioria de seus textos didáticos em co-autoria. Desde 1976, teve como parceiro o Prof. Adhemar e, desde 1986, juntou-se a eles o Prof. Flávio, que já havia formulado exercícios para a 2a edição da coleção Nossa História, em 1984.

É certo que a tarefa de publicar tantas coleções, adequadas a tantos programas diferentes de História, em um prazo de tempo tão curto, será mais facilmente executada com o trabalho de três autores e não de um só. Este fato assinala que uma nova coleção não significa necessariamente uma nova forma de expor a matéria ou a entrada de novos conteúdos; é claro que eles ocorrem, mas, muitas vezes, uma nova coleção só é feita para atingir mercados específicos que possuem programas específicos e, neste caso, nem sempre as mudanças são muito profundas, por vezes, são apenas a reordenação de velhos

\footnotetext{
${ }^{12}$ São elas História Moderna através de textos, de 1989 e História Contemporânea através de textos, de 1990, com autoria coletiva de Ricardo Moura Faria, Adhemar Martins Marques e Flávio Costa Berutti.
} 
conteúdos. É claro que a entrada dos recursos da informática nas editoras agilizou em muito esta tarefa de fazer e refazer coleções.

0 Prof. Ricardo relatou que as dificuldades de compreensão pelo professorado dos procedimentos didático-pedagógicos que eram necessários para a utilização da coleção Construindo a História, destinada aos alunos de $5^{\text {a à }} 8^{a}$ séries e publicada em 1987, foram determinantes para a publicação da coleção "História: os caminhos do homem", em 1991. Segundo ele, [ela] vendeu muito bem e ficou dez anos no mercado, mas com muito pouco resultado favorável, pois o professorado não estava usando o livro como nós propusemos e, sim, do modo tradicional. ${ }^{13}$

De fato, na coleção Construindo a História foram inseridos para 0 desenvolvimento de cada um dos temas quatro ou cinco textos. Estes textos apresentavam diferentes versões ou mesmo abordagens sobre o mesmo tema. Caberia ao professor levar os alunos a perceberem essas diferenças para a partir delas realizarem a construção de seu conhecimento. Ao invés disso, os professores utilizavam o livro do modo como já estavam acostumados, ou seja, faziam com que os alunos decorassem todos os textos, como se fossem um única coisa, avaliando, por meio das provas, se eles haviam aprendido.

Tanto o Prof. Ricardo quanto o Prof. Jobson começaram a publicar em editoras que nos anos setenta eram pequenas, mas que hoje estão entre as maiores do ramo didático. É interessante observar, também, o fato de que os livros didáticos do começo dos anos setenta eram impressos em preto e branco e hoje, especialmente, os de $1^{\circ}$ grau são, em sua maioria, impressos a quatro cores. Os de $2^{\circ}$ grau, salvo algumas exceções, são impressos com uma cor além do preto\&branco.

De fato, a modernização dos recursos de edição dos livros didáticos atuais tem possibilitado a melhoria do padrão estético dos mesmos. 0 uso das cores é uma marca dos livros de $1^{\circ}$ grau, em que existem mais ilustrações, boxes e outros recursos de edição e formatação do texto. Os livros de $2^{\circ}$ grau são, tradicionalmente, mais despojados que os de primeiro grau. Neles, o privilégio sempre esteve no texto escrito e não nos filigranas e ilustrações. Muitos deles, na atualidade, trazem indicações de filmes que se relacionam com o conteúdo que está sendo desenvolvido em um determinado capítulo do

${ }^{13}$ Ricardo de Moura FARIA e Flávio Costa BERUTTI. op. cit. p. 127. 
livro, o que revela uma certa interação de meios antes distantes que são os literatura e o cinema.

Desde os anos setenta, como lembrou o Prof. Ricardo, os editores de livros didáticos de $1^{\circ} \mathrm{e} 2^{\circ}$ graus procuram um formato/tamanho para os mesmos. Os livros de $1^{\circ}$ grau da área de História consolidaram, na década de setenta, 0 formato 21x 28 e o máximo de 180 páginas como um padrão que é respeitado pela quase totalidade de editoras de livros didáticos. Os livros de História para 0 $2^{\circ}$ grau sofreram maior demora mais a consolidar um padrão, mas, nos anos noventa, quase todos adotaram o formato $17 \times 23$ ou algo perto disso e no máximo de 550 páginas.

\section{Considerações Finais}

De fato, os livros didáticos têm sido o reflexo de uma determinada memória histórica consolidada. Porém, consolidada onde? Essa memória oficiosa e elitista que os livros didáticos perpetuaram por décadas foi mais permanente no cenário escolar. No cenário acadêmico, ela perdeu muita força desde os anos trinta, com a publicação de diversos textos críticos e vinculados a História Econômica. Mas, na escola, que sofreu a ingerência dos governos ditatoriais na determinação de seus conteúdos, no período de 1930 a 1945 e, depois, de 1964 a 1984, uma História mais crítica teve dificuldade de penetração, pelo menos até meados dos anos setenta, com o advento da abertura "lenta, gradual e segura" empreendida pelo governo Geisel.

0 esforço de desconstrução contido em alguns dos textos dos professores Ricardo, Flávio e Adhemar foi uma tentativa interessante, mas que necessitava de um professor que fosse capaz de levar os alunos a uma reflexão tão sofisticada quanto essa. De qualquer maneira, a dificuldade maior, como eles e o Prof. Jobson salientaram, consiste na capacidade de não reduzir à História a maniqueísmos tolos de heróis e vilões, mas sim compreender a enorme complexidade que envolve os fenômenos sociais e históricos.

Em síntese, pôde-se perceber que a formação acadêmica dos autores analisados tem como base comum à área de História, mas todos diferem quanto ao preparo para o desenvolvimento da pesquisa de ponta na área. Apenas um dos autores tem o doutorado e produção de conhecimento divulgada 
amplamente. Em comum, todos têm o fato de terem tido forte experiência no ensino escolar da disciplina, com prevalência do ensino particular sobre 0 público, o que, segundo, os próprios autores foi determinante em sua capacitação para a escrita de livros didáticos. A censura à livre expressão determinada pelo regime militar foi destacada por todos como variável que intervia em sua produção didática. Somente nos anos oitenta do Século XX é que, aos poucos, houve segurança para a inserção de temáticas e análises críticas com mais liberdade. Sem dúvida, os conteúdos escolares, propagados nos livros didáticos e muito controlados pelo regime militar, contribuíam para a formação da memória nacional desejada, ainda que as obras didáticas dos autores mencionados conseguissem, em diversos temas, veicular raciocínio crítico sobre o passado que forneciam subsídios importantes para que docentes e alunos pudessem formular seus juízos sobre a realidade sócio-histórica.

\section{Materiais Históricos}

\section{Livros Didáticos Consultados}

ARRUDA, José Jobson de Andrade \& PILETTI, Nelson. Toda a História: História Geral e História do Brasil.6ª ed. São Paulo. Ática. 1996.

ARRUDA, José Jobson de Andrade. História Antiga e Medieval: coleção de textos. São Paulo. Grêmio da Faculdade de Filosofia/USP. 1966 atividades).

. História Antiga e Medieval. 5 a ed. São Paulo. Ática. 1982.(inclui caderno de História Moderna e Contemporânea. $8^{a}$ ed. São Paulo. Ática. 1977.

História Moderna e Contemporânea. $18^{a}$ ed. São Paulo. Ática. 1985.(inclui caderno de atividades).

. História Moderna e Contemporânea: (Série compacta). São Paulo. Ática. 1986.(inclui exercícios e questões de vestibular).

. História Moderna e Contemporânea. $24^{\mathrm{a}}$ ed. São Paulo. Ática. 1991.

História Integrada: da Pré-História ao fim do Império Romano. 4 vol. $2^{\mathrm{a} e d .}$ São Paulo. Ática. 1996.(inclui manual do professor e bloco de atividades). 
FARIA, Ricardo de Moura. Nova História Geral. 2 vols. Belo Horizonte. Lê. 1975.

FARIA, Ricardo de Moura, DUARTE, Gleuso Damasceno, MARUM, Antônio, Guimarães \& Tânia Maria. Estudos Sociais. 4 vols. Belo Horizonte. Lê. 1979.

FARIA, Ricardo de Moura, MARQUES, Adhemar Martins. Síntese de História. 4 vols. Belo Horizonte. Lê. 1980.(inclui manual do professor).

. Nova História: $2^{\circ}$ grau e vestibulares. Belo Horizonte. Lê. 1982.

Nossa História: História do Brasil. 2 vols. Belo Horizonte. Lê. 1984.(inclui orientações didáticas e caderno de exercícios).

Nossa História: História Geral. 2 vols. Belo Horizonte. Lê. 1984. (inclui orientações didáticas e caderno de exercícios).

FARIA, Ricardo de Moura et alii. Construindo a História. 4 vols. Belo Horizonte. Lê. 1987. (inclui orientações metodológicas).

. História: os caminhos do homem. 4 vols. Belo Horizonte. Lê. 1991.

História. 3 vols. Belo Horizonte. Lê. 1995.

. História: antiga e medieval. Belo Horizonte. Lê. 1996.

. Brasil:História em construção. 4 vols. Belo Horizonte. Lê. 1996.

NEVES, Joana, NADAI, Elza, ABUCARMA, Suria. Estudos Sociais: a formação do estado brasileiro e a diversificação regional ( $6^{a}$ série do $1^{0}$ grau). $4^{a}$ ed. São Paulo. Saraiva. 1982. (inclui cadernos de exercícios).

NEVES, Joana, NADAI, Elza, ABUCARMA, Suria. Estudos Sociais: o processo de ocupação do espaço brasileiro ( $5^{a}$ série do $1^{\circ}$ grau $) .6^{a}$ ed. São Paulo. Saraiva. 1983.(inclui cadernos de exercícios).

NEVES, Joana, NADAI, Elza. História do Brasil: Brasil independente. São Paulo. Saraiva. 1985.(inclui manual do professor).

História Geral: antiga e medieval. $2^{a}$ ed. São Paulo. Saraiva. 1988.(inclui orientações metodológicas).

História Geral: Moderna e Contemporânea. $5^{a}$ ed. São Paulo. Saraiva. 1988.(inclui orientações metodológicas).

. História do Brasil: Brasil colônia.. 9a ed. São Paulo. Saraiva. 1989.

. História da América. 12a ed. São Paulo. Saraiva. 1989. 
História do Brasil: da colônia à República. 12ª ed. São Paulo. Saraiva. 1989. História do Brasil: da colônia à República. 15ª ed. São Paulo. Saraiva. 1993.( inclui manual do professor).

História do Brasil. 16ª ed. São Paulo. Saraiva. 1995. (inclui manual do professor).

\section{Depoimentos}

1. Joana Neves

2. José Jobson de Andrade Arruda

3. Ricardo de Moura Faria

4. Flávio Costa Berutti

\section{Bibliografia Consultada}

APPLE, Michael W. Cultura e Comércio do Livro Didático. In: Trabalho Docente e Textos: Economia Política das Relações de Classe e de Gênero em Educação. Porto Alegre. Artes Médicas. 1995. p. 81-105.

BITTENCOURT, Circe M F. Pátria, Civilização e Trabalho: 0 Ensino de História nas Escolas Paulistas (1917- 1939). São Paulo. Loyola. 1990.

. Livro Didático e Conhecimento Histórico (Tese de Doutorado). São Paulo. FAE/USP. 1993. .(org.) Livros didáticos entre textos e imagens. O saber histórico em sala de aula. São Paulo. Contexto. 1997.

BUFFA, Ester et alii. Educação e Cidadania: quem educa o cidadão?. $3^{\mathrm{a}}$ ed. São Paulo. Cortez/Autores Associados. 1991.

CÂMARA BRASILEIRA DO LIVR0. Comportamento do Setor Editorial Brasileiro-1990/ 1996.

CARVAlHo, Anelise M. M. Pregadores de Idéias, Animadores de Vontades - Livros Didáticos, nos Anos 1930/1940. (Dissertação de Mestrado). São Paulo. PUC-SP. 1992. CARVALHO, Lídia I. A Distribuição e Circulação de Livros nas Escolas Paulistas. (Dissertação 
de Mestrado). São 0 livro didático em questão. 2a. Ed.. São Paulo. Cortez. 1993.

CHARTIER, Roger \& ROCHE, Daniel. O Livro: uma mudança de perspectiva. In: LE GOFF, Jacques \& NORA, Pierre.(org.) Fazer História: Novos Objetos - Terceiro Volume. Venda Nova. Bertrand (Coleção Tempo Aberto). 1987.

CHARTIER, Roger. Textos, impressão, leituras. In: HUNT, Lynn (org.). A Nova História Cultural. São Paulo. Martins Fontes (Coleção: 0 Homem e a História). 1992. p. 211-238.

DARNTON, Robert. 0 que é História dos Livros? In: 0 Beijo de Lamourette: mídia, cultura e revolução. São Paulo. Companhia das Letras. 1990. p. 109-131.

FEBVRE, Lucien, MARTIN, Henri-Jean. O Aparecimento do Livro. São Paulo. UNESP/ HUCITEC. 1992.

FERNANDES, Daniela. Editoras esperam faturar R $\$ 2$ bi em 96. Folha de S.Paulo. 21/ 10/96. c.2. p1.

FREITAG, Bárbara, MOTTA, Valéria Rodrigues, COSTA, Wanderly Ferreira da. O Livro Didático em Questão. $2^{a}$ ed. São Paulo. Cortez.1993.

GATTI JR., Décio. História, Educação e Projeto Social. (Dissertação de Mestrado). PUCSP. 1993.

. Livro Didático e Ensino de História: dos anos sessenta aos nossos dias. (Tese de Doutorado). PUC-SP. 1998.

HALLEWELL, Laurence. O livro no Brasil: sua história. São Paulo. EDUSP.1985.

INEP - Instituto Nacional de Estudos e Pesquisas Educacionais. 0 Livro Didático: velho tema revisitado. Em Aberto. Brasília. Ano VI. no. 35. jul.-set. 1987.

MATELA, Rose Clair Pouchain. O professor de História e o livro didático: uma relação delicada.(Dissertação de Mestrado). UFF-RJ. 1994.

MUNAKATA, Kazumi. Produzindo Livros Didáticos e Paradidáticos. (versão preliminar). PUC-SP. set. de 1994.

. Produzindo Livros Didáticos e Paradidáticos. (Tese de Doutorado). PUC-SP. 1997.

OLIVEIRA, João Araújo B., et alii. A Política do Livro Didático. São Paulo, Summus. Campinas, Editora da Universidade Estadual de Campinas. 1984.

SOARES, Magda Becker. Um olhar sobre o livro didático. Presença Pedagógica. Belo Horizonte. 2 (12) 54-63. nov./dez. 1996 


\section{University professors that write didactic books: analysis of testimonies of contemporary brazilian authors}

\section{ABSTRACT}

This deals with the communication of historical-pedagogical reflections undertaken in the area of History of School Disciplines, in which the analytical perspective was socio-historical focusing on the examination of the content of collected testimonies at the end of the 1990s in association with some university professors in the southeast and northeast regions of Brazil. These university professors also became important authors of didactic books of Brazilian History at the end of the 1960s and beginning of the 1970s. In this reflection, the biographical data of the authors were gathered and analyzed; especially as regards academic formation, teaching experience in the classroom, the course and impact of the military regime and return to democracy on didactic production, and understanding of the function of a didactic book and of the form in which the transmitted content contributes to the formation of the national memory. The task of publishing associated with didactic production currently demands authors that can bring together the ability of writing in accessible language with the possibility of frequently updating content - authors who are also open to sharing responsibility with various other professionals for the production of their didactic work.

Key-words: university professor, didactic books, national memory. 